\title{
The Survival of a Woman: A Feminist Approach to Winnie-the-Pooh and The House at Pooh Corner
}

\author{
Ya Long ${ }^{1}$ \\ ${ }^{1}$ School of Foreign Languages, Chongqing Technology and Business University, Chongqing, China \\ Correspondence: Ya Long, School of Foreign Languages, Chongqing Technology and Business University, \\ Chongqing 400067, China. E-mail: y.long@ctbu.edu.cn
}

Received: October 25, 2014 Accepted: November 30, 2014 Online Published: February 25, 2015

doi:10.5539/ells.v5n1p57 URL: http://dx.doi.org/10.5539/ells.v5n1p57

\begin{abstract}
The Pooh stories in Winnie-the-Pooh and The House at Pooh Corner by A. A. Milne try to create a "friendly-for-all" climate in the paradise-like forest. While the male residents enjoy the adventures, explorations and games, Kanga, the only female character in the forest, is excluded and marginalized. This paper examines how Kanga, struggling against the pervasive patriarchal power, survives and eventually wins a place in the male dominated community.
\end{abstract}

Keywords: feminist approach, the Poor stories, marginalized women, patriarchal community, subversive mother figure

\section{Introduction}

The Pooh stories in Winnie-the-Pooh (1926) and The House at Pooh Corner (1928) by A. A. Milne try to create a "friendly-for-all" climate in the paradise-like forest. It is perhaps true for most of the male residents in the forest that they do enjoy the adventures, explorations and games that Milne the male writer has offered. But there is one who is excluded and marginalized. It is Kanga, the only female character in the stories. Facing the unfavorable living environment, however, she survives and wins a position in the end by struggling against the pervasive patriarchal power in her own way.

\section{The survival of Kanga}

Kanga's first appearance is much delayed till the seventh chapter of Winnie-the-Pooh. Her story begins in medias res. It happens to be a conventional way of starting an epic, a very masculine form of literature. But unfortunately Kanga is not treated as important as those overstated epic heroes. She is placed in a marginal position and prevented from having more influence in the stories afterwards at least in terms of page coverage. The direct result of Milne's meager account of Kanga is her passive engagement in communal activities. She is absent from searching for Small and building a house for Eeyore. Even in the few events she is involved in, she is never a leading figure, but instead plays a foiling role. In the expedition to the North Pole, all the men are too impatient to wait for the coming adventure and are busy organizing the trip.

There was a shout from the top of the line.

"Come on!" called Christopher Robin.

"Come on!" called Pooh and Piglet.

"Come on!" called Owl.

"We're starting," said Rabbit. "I must go." And he hurried off to the front of the Expotition with Christopher Robin.

“All right," said Eeyore. “We're going. Only Don't blame me.”(p. 105)

Kanga's voice can hardly be heard among her partners. It seems that she is not expected to be interested in such a masculine business as adventure. A woman is not supposed to be entitled to be courageous, curious nor extrovert. It implies that her territory is only in the domestic area such as at home. It is easy to notice that Kanga is missing in Pooh's verse for the exploration. 
They all went off to discover the Pole,

Owl and Piglet and Rabbit and all;

It's a Thing you Discover, as I've been tole

By Owl and Piglet and Rabbit and all.

Eeyore, Christopher Robin and Pooh

And Rabbit's relations all went too -

And where the Pole was none of them knew....

Sing Hey! for Owl and Rabbit and all! (p. 106)

All are embraced in the mission-Christopher Robin, Pooh, Piglet, Rabbit, Owl, Eeyore and even Rabbit's relations. Only Kanga is excluded. Perhaps she is too different to be included. But it is hard to deny the fact that Kanga is an irreplaceable witness of the great discovery of the North Pole, when Pooh holds one end of the pole and she holds the other between the two pools to save drowning Roo (p. 112). However, she is not even recognized as one of the participants, not to mention the justification of her role in such a historic issue which deserves documenting - Christopher Robin ties a message to the pole, on which it is written that the north pole is discovered by Pooh (p. 116). The role granted to a woman is to applaud a man's heroic behavior with admiration and that is what Kanga is assigned to do according to E. H. Shepard's illustration in the ending of the North Pole exploration (p. 116). Additionally one more note is perhaps needed to clarify his illustration, "it is generally true that gender is constructed in patriarchy to serve the interests of male supremacy" (Greene \& Kahn, 1985, p. 3).

Kanga has been excluded and regarded as "Other" since her presence at the forest. She is "a Strange Animal" in Rabbit's words and "a Fierce Animal" according to Piglet simply because she "carries her family about with her in her pocket" (pp. 83-84). What makes Kanga different is her pouch, a female organ that stirs up the uneasiness among her male neighbors. If the situation is put the other way round, what Kanga lacks is the male organ that the others possess. As feminist theory puts it, the male physical organ is considered as "an emblem of social power and the advantages which go with it" (Barry, 2002, p. 131). Accordingly Rabbit takes advantage of his position to plot the drive-Kanga-out farce.

The role of a woman is always defined in the domestic sphere as she lacks a penis and is a natural bearer of children. Therefore she should be more responsible for homemaking. In the Pooh stories the fundamental question of where children come from is aroused with the coming of Kanga.

Nobody seemed to know where they came from, but there they were in the forest: Kanga and Baby Roo. When Pooh asked Christopher Robin, "How did they come here?" Christopher Robin said, "In the Usual Way, if you know what I mean, Pooh," and Pooh, who didn't, said "Oh!” Then he nodded his head twice and said, "In the Usual Way. Ah!" (p. 81)

Thus it is indicated that they all of them come in "the Usual Way", that is, women give birth to children. The universally accepted truth helps to naturalize and legitimize the social role of women as child bearers and nurturers. Kanga is hardly able to escape the hegemony. Most of her stories happen indoors where she is busy with household chores and nurturing. Even so that at Pooh's party, she is also occupied with feeding Roo milk and patting his back when he is choking (pp. 139-140). Female biology determines her domestic role in society. Milne depicts this prevailing image of a woman. She is the same everywhere. The stereotype obscures her uniqueness. As feminist scholars argue, "That men have penises and women do not, that women bear children and men do not, are biological facts which have no determining meaning in themselves but are invested with various symbolic meanings by different cultures" (Greene \& Kahn, 1985, p. 2).

The social castration not only tries to localize a woman physically at home and keep her far from the center of the political power but also attempts to depress her intellectual freedom. As Gayle Greene and Coppélia Kahn point out, "a male perspective, assumed to be universal, has dominated fields of knowledge, shaping their paradigms and methods" (Greene \& Kahn, 1985, pp. 1-2). The scholarly Owl seems enthusiastic about showing off his learnedness to Kanga by telling her "an Interesting Anecodote full of long words like Encyclopadia and Rhododendron" (p. 110). He must also disdain that Kanga is hardly interested in Pooh's poetry (p. 89), a masculine tradition of literature (Note 1). A woman is presumed to be inferior in the "privileged" academic field. However, it does not hinder Kanga from telling the truth, in The House at Pooh Corner, when she helps clear the relics of Owl's old house after it is blown down from the tree, that "it was quite time it did tumble down" since it is "all damp and dirty". But a "sarcastic laugh" instead of an appreciative one is thrown back upon her. Owl satirizes, "if people didn't know a perfectly ordinary bath-sponge when they saw it, things were coming to a 
pretty pass". Owl's authority cannot be challenged as he is the one "who can spell TUESDAY". How dare a woman without any insight doubt his scholarship? But the truth is as clear as a crystal, so that even a baby has already recognized it. Roo says, “it isn't a sponge, it's a spudge! Do you know what a spudge is, Owl? It is when your sponge gets all -" (p. 153). Ironically, a man's self-complacency invites the questioning of his pseudo-intellectualism by an "unknowledgeable" woman in the end.

Kanga's confrontation with a gang of self-righteous men can be traced back to her first appearance in the forest, which foreshows the difficulties she might encounter in such a male dominated community. But she successfully solves the crisis with her woman's strategy and survives her stay. In Winnie-the-Pooh, When Kanga returns home, she finds that the one who stays in her pocket is not her baby Roo, but Piglet. She knows immediately that they are playing tricks on her. But she does not make it known. Instead in return she plays the same trick upon Piglet, one of Rabbit's accomplices that they have played upon her.

"Now then, Roo, dear," she said, as she took Piglet out of her pocket. "Bed-time."

"Aha!" said Piglet, as well as he could after his Terrifying Journey. But it wasn't a very good "Aha!" and Kanga didn't seem to understand what it meant.

"Bath first," said Kanga in a cheerful voice.

"Aha!" said Piglet again, looking round anxiously for the others. But the others weren't there ...

"I am not at all sure," said Kanga in a thoughtful voice, "that it wouldn't be a good idea to have a cold bath this evening. Would you like that, Roo, dear?"

Piglet, who had ever been really fond of baths, shuddered a long indignant shudder, and said in as brave a voice as he could:

"Kanga, I see that the time has come to speak plainly."

"Funny little Roo," said Kanga, as she got the bathwater ready.

"I am not Roo," said Piglet loudly. "I am Piglet!"

"Yes, dear, yes," said Kanga soothingly. "And imitating Piglet's voice too! So clever of him," she went on, as she took a large bar of yellow soap out of the cupboard. "What will he be doing next?"

"Can’t you see?" shouted Piglet. "Haven't you got eyes? Look at me!"

"I am looking at you, Roo, dear," said Kanga rather severely. "And you know what I told you yesterday about making faces. If you go on making faces like Piglet, you'll grow up to look like Piglet - and then think how sorry you will be. Now then, into the bath, and don't let me have to speak to you about it again."

Before he knew where he was, Piglet was in the bath, and Kanga was scrubbing him firmly with a large lathery flannel.

"Ow!" cried Piglet. "Let me out! I am Piglet!"

"Don't open the mouth, dear, or the soap goes in," said Kanga. "There! What did I tell you?"

"You - you - you did it on purpose," spluttered Piglet, as soon as he could speak again... and then accidentally had another mouthful of lathery flannel.

"That's right, dear, don't say anything," said Kanga, and in another minute Piglet was out of the bath, and being rubbed dry with a towel.

"Now," said Kanga, "there's your medicine, and then bed."

"W-w-what medicine?" said Piglet.

"To make you grow big and strong, dear. You don't want to grow up small and weak like Piglet, do you? Well, then!” (pp. 93-96)

Piglet desperately claims that he is not Roo. In his logical argumentation, most linguistic elements of his reasoning, such as syntax, signs and nomination, are established and fixed. By contrast, Kanga's discourse is characterized by "“displacement, slippage, and condensation"”. She plays with the concepts of Piglet, Roo and Roo who is making faces. It is "a much looser, more randomised way of making connections, one which increases the available range of possibilities" (Barry, 2002, pp. 128-129). It fits in with the semiotic aspect of language in Julia Kristeva's terms. As Ann Rosalind Jones interprets Kristeva's linguistic notion of symbolic and semiotic, "women's strategy should be neither to adopt masculine modes of power nor to flee encounters with the symbolic, but to assume 'a negative function: reject everything finite, definite, structured, loaded with 
meaning, in the existing society. Such an attitude puts women on the side of the explosion of social codes: with revolutionary movements"' (Greene \& Kahn, 1985, p. 86). Kanga successfully violates men's conspiracy and blows up their arrogance by a feminine approach. Her rebellious action allows her to survive in a living place at the level of practical meaning. It is more significant that she challenges the stereotyped image of unconfident and humorless women portrayed by the patriarchal world.

Having no say in the public realm, a woman is largely confined within domestic affairs. But the feminine valuing of domestic and maternal ideas is dwarfed by the disproportionate emphasis on adventure, power, honor and public success. Few can fail to be touched by Kanga's motherly warmth and generosity when Tigger is at the edge of emotional breakdown, without food to eat and without a place to stay at. Kanga knows that "however big Tigger seemed to be, he wanted as much kindness as Roo" (House, p. 30). What Kanga offers is not simply room and board but a cozy family full of her unselfish love. Whereas no one ever has the least inclination of giving her any credit by throwing a party for example, as Christopher Robin does for Pooh or by dedicating a piece of poetry such as Pooh writes for Piglet. In the ideology of the male dominated community, only such so called "grand things" seem worth remembering as rescuing someone from a flood or saving some detainees from the collapsed shabby house. What Kanga does for Tigger is easily devaluated; for women are regarded as the natural caretakers and nurturers of children based on the biological grounds that females have a maternal instinct. The naturalization of women's maternal role covers up the fact it is also a process of social learning or social construction. In Kanga's case, her experience of being nearly blackmailed at her initial arrival at the forest with Roo makes her more sympathetic to a stranger who finds himself in a situation much like hers before. In this sense, Kanga identifies herself with Tigger as an outsider to the forest. She transcends the hierarchal power which dominates the male world to a philanthropic power which enables her to pacify the overtly masculine community. It is not too hard to predict what might happen if a big and bouncy predatory animal like Tigger were left alone without anyone taking good care of him. Besides, as an aftereffect of adopting Tigger, Kanga causes another miracle to happen, namely that she even transforms Tigger to be a vegetarian by feeding him an extract of malt, which makes him stronger but less fierce. It is easy to explain why Tigger does not even intend to avenge the ill-disposed Rabbit after Rabbit whips up a group and tries to unbounce him. Thanks to the influence of Kanga's philanthropic philosophy, Tigger rescues Rabbit from being lost in the forest instead (Houser, pp. 119-124). Touched by Tigger's heroic behavior, Rabbit cannot help crying, "a Friendly Tigger, a Grand Tigger, a Large and Helpful Tigger" (House, p. 124). As a matter of fact, there is a more friendly, grand and helpful woman behind him. Unfortunately, Milne's meanness towards Kanga makes her appearance insufficient. Otherwise, surely Piglet would not have needed to make up an imaginary parental figure "grandpa Trespassers William" for his protection (Winnie, p. 30).

Historically the recognition of a woman's contribution to society has always been much more difficult to achieve. The same applies to Kanga. As a mother she bears the hardship of bringing up two children. If there is one who still labors in such a worldly paradise, where everyone enjoys the benefit of social welfare and does not feel the necessity to work, it must be Kanga. Instead of relying on the social welfare system, she works seriously and devotedly though her job is scorned as trivial and "motherly". She counts "Roo's vests, and how many pieces of soap there were left, and the two clear spots in Tigger's feeder" and also prepares "a packet of watercress sandwiches for Roo and a packet of extract-of-malt sandwiches for Tigger" (House, p. 58). She is even much more occupied than Rabbit in his busy day, when Rabbit is fussing over a piece of note and is busy discovering what Christopher Robin does. Rabbit's business sets off the importance of Kanga's work. The children she is taking care of are not simply the offspring of her own, but the inheritors of the community. It matters for the continuity of their society. Kanga is not only a breadwinner but also an educator of the next generation. As Carol Smart remarks, a mother is also a tutor with "source of special knowledge that was essential to the good rearing of a child" (Silva, 1996, p. 45). Kanga plays the role of moral model for her children. She imparts them with the value of working by sending them to collect fir-cones (House, p. 118); she teaches Roo a technique of survival by encouraging him to jump well (Winnie, p. 88); she shows Tigger how to get along with others by telling him to be gentle (House, p. 58). Her instruction proves to be essential and beneficial. Roo saves himself from the tree by a good jump (House, p. 67); Tigger even befriends gloomy Eeyore by playing Poohsticks with him (House, p. $105)$.

\section{Conclusion}

As a single mother, Kanga needs more courage and wisdom to take the responsibility of rearing than a common mother. Her contribution is more far-reaching than only in the domestic sphere. The absence of Roo's father does not frustrate her determination to rear her son alone. She not only demonstrates her ability to rear a child without a husband but also adopts another child Tigger. Kanga undergoes the conventional disapproval of a single mother 
and enters "bachelor motherhood" (Silva, 1996, p. 17) as a statement to deconstruct the values of the traditional nuclear family where the wife is subsumed under her husband's political and legal status. Furthermore, Kanga disregards the long-established way of naming a child after its father. As French feminists claim, "a patriarchal monopoly upon naming has left no voice whatever for women” (Greene \& Kahn, 1985, p. 239). But Kanga smartly expresses her voice by calling her baby Roo since her official name Kangaroo consists of Kanga and Roo. It suggests a close mother-child bond and undermines the legacy of father naming. In this sense, Mother Kanga is not subordinate but subversive. She is a demotic mother and also to some extent a social reformer. She participates in the social life and influences the people around her in such a way that is not flaunting but it is still far-reaching in the long run.

However, it is too hasty to jump to the conclusion that Kanga is a woman with feminine self-consciousness. She has her own weaknesses. Her education of the young may be too pedagogic though she means well. Her excessive care for Roo might be suffocating, for Roo once fell into the river on purpose to escape from her eyesight (House, p. 104). Kanga is taking the risk of losing her own individuality by binding herself too tightly to the mother-child relationship. There would be no Kanga any longer but only Roo's mother. Besides, as Roo complains of Kanga, "you're always seeing, and nothing ever happens" when Roo wishes to join in an exploration with Tigger and others (House, p. 111). The inaction of a woman may result in her anaesthetization of the present situation and of falling into the masculine ideology. Thus Kanga still seems to have a fantasy on phallogocentrism. Her witty plan to breach the phallic drive-out plot by Rabbit, Roo and Pooh is based on her trust that "Christopher Robin would never let any harm happen to Roo" (Winnie, p. 93). Nonetheless, as Jeanne Lorraine Schroeder puts it, "The Feminine is the silent Phallic Mother who is always already lost in castration. But she is also the freedom of not being bound by the law of castration which has not yet been achieved" (Crews, 2002, p. 48). The moment that Kanga signs her name on the sheet of paper with all the others' names also on it at the end of the Pooh stories is worth documenting as much as when Pooh discovers the North Pole (House, p. 164). It is not only a moment to prove her literacy but also, more significantly, a moment to declare that she has the same right as men. In this sense, what Kanga has achieved is not simply a place to survive, but a success as a woman in a man's world, an example for other marginalized women to follow.

\section{References}

Barry, P. (2002). Beginning Theory: an Introduction to Literary and cultural Theory. Manchester and New York: Manchester University Press.

Crews, F. C. (2002). Postmodern Pooh. London: Profile Books.

Greene, G., \& Kahn, C. (Eds.). (1985). Making a Difference: Feminist Literary Criticism. London and New York: Methuen.

Milne, A. A. (1926 repr. 1965). Winne-the-Pooh. London: Methuen.

Milne, A. A. (1928 repr. 2003). The House at Pooh Corner. London: Methuen.

Silva, E. B. (Ed.). (1996). Good Enough Mothering?: Feminist Perspective on Lone Mothering. London: Routledge. http://dx.doi.org/10.4324/9780203434284

Woolf, V. (1993 repr. 2000). A Room of One's Own. London: Penguin.

\section{Note}

Note 1. Virginia Woolf argues that women have less chance of writing poetry because they have less intellectual freedom in A Room of One's Own (London: Penguin, 2000), p. 97.

\section{Copyrights}

Copyright for this article is retained by the author(s), with first publication rights granted to the journal.

This is an open-access article distributed under the terms and conditions of the Creative Commons Attribution license (http://creativecommons.org/licenses/by/3.0/). 